\title{
Histogram Analysis of Computed Tomography Images for Quantitative Assessment of Gastric Cancer Invasiveness
}

\section{Mide Kanseri İnvazifliğinin Kantitatif Değerlendirmesinde Bilgisayarlı Tomografi Histogram Analizi}

\author{
(D) Aytül Hande Yardımcı ${ }^{1}$, (D) Özlem Mermut², (D) Veysi Hakan Yardımcı ${ }^{3}$, (D) Ipek Sel ${ }^{4}$, (D) Ceyda Turan Bektaş ${ }^{4}$ \\ 1 University of Health Sciences Turkey, İstanbul Başakșehir Çam and Sakura City Hospital, Clinic of Radiology, İstanbul, Turkey \\ 2University of Health Sciences Turkey, İstanbul Training and Research Hospital, Clinic of Radiation Oncology, İstanbul, Turkey \\ 3 İstanbul Gelișim University Faculty of Health Sciences, İstanbul, Turkey \\ ${ }^{4}$ University of Health Sciences Turkey, İstanbul Training and Research Hospital, Clinic of Radiology, İstanbul, Turkey
}

\begin{abstract}
Introduction: To explore the role of computed tomography (CT) texture analysis in predicting T-stage of gastric cancers (GC).

Methods: Preoperative enhanced CT images of 110 patients (men: 84, women: 26) with GC were reviewed retrospectively. Regions of interest were manually drawn along the margin of the lesion on the section where it appeared largest on the portal venous CT images, which yielded texture parameters (1, 10, 50, 90, and 99\% percentiles; minimum, mean, and maximum norm; variance; skewness, and kurtosis). Correlations between texture parameters and pathological stage were analysed with Spearman's correlation test. The distributions of all variables were checked with the aid of the Kolmogorov-Smirnov test. The Independent-Samples t-test and the Mann-Whitney $U$ test were used (as appropriate) to compare quantitative data. The chi-squared test was employed to compare qualitative data. The diagnostic performance of CT texture parameters in differentiating different stages was evaluated using receiver operating characteristic analysis.
\end{abstract}

Results: The T4 variance was significantly greater than that of the T1-to-T3 group $(p<0.05)$. The T4 skewness was significantly lower than that of the T1-to-T3 group $(p<0.05)$ but the T4 kurtosis significantly higher $(p<0.05)$.

Conclusion: The histogram parameters of CT-TA, especially skewness and kurtosis derived from portal, venous phase CT images, may serve as biomarkers stratifying the risk of serosal invasion (stage-T4) by locally advanced GC. Thus, histogram analysis can be used preoperatively to evaluate serosal invasion.

Keywords: Gastric cancer, T-staging, CT, histogram analysis

\section{ÖZ}

Amaç: Mide kanserlerinin (MK) T-evresini tahmin etmede bilgisayarlı tomografi (BT) doku analizinin rolünü keșfetmektir.

Yöntemler: MK'li 110 hastanın (erkek: 84, kadın: 26) ameliyat öncesi geliștirilmiş BT görüntüleri retrospektif olarak incelendi. İlgi bölgeleri, doku parametreleri (1, 10, 50, 90 ve \%99 persentiller; minimum, ortalama ve maksimum norm; varyans; çarpıklık ve basıklık). Doku parametreleri ile patolojik evre arasındaki ilişkiler Spearman korelasyon testi ile analiz edildi. Tüm değișkenlerin dağılımları Kolmogorov-Smirnov testi yardımıyla kontrol edildi. Niceliksel verileri karşılaştırmak için Independent-Samples t-test ve Mann-Whitney $U$ testi (uygun şekilde) kullanıldı. Nitel verileri karşılaştırmak için ki-kare testi kullanılmıştır. Farklı aşamaları ayırt etmede CT doku parametrelerinin tanısal performansı, alıcı ișletim karakteristiği analizi kullanılarak değerlendirildi.

Bulgular: T4 varyansı, T1-T3 grubuna göre anlamlı derecede daha yüksekti $(p<0,05)$. T4 çarpıklığı, T1-T3 grubuna göre anlamlı derecede düşüktü $(p<0,05)$, ancak T4 basıklığı anlamlı derecede yüksekti $(p<0,05)$.

Sonuç: BT doku analizi histogram parametreleri, özellikle portal, venöz faz BT görüntülerinden türetilen çarpıklık ve basıklık, lokal olarak ilerlemiş mide tümörlerinde serozal invazyon riskini (evre-T4) katmanlandıran biyobelirteçler olarak hizmet edebilir. Bu nedenle, histogram analizi, serozal invazyonu değerlendirmek için preoperatif olarak kullanılabilir. Anahtar Kelimeler: Mide tümörü, T-evreleme, BT, histogram analizi 


\section{Introduction}

Although the incidence of, and mortality from, gastric cancer (GC) have decreased recently, GC remains the fifth most common cancer and the third leading cause of cancer deaths worldwide (1). Treatment options are limited beacuse many patients exhibit locally advanced cancer at diagnosis (stages T4a, 4b, and N1,2,3). New diagnostic options for locally advanced GC and identification of patient subgroups who can benefit from personalised treatments have become prime research topics (2-4). Multidetector computed tomography (MDCT) is often the primary method used for preoperative GC staging and shows promise in terms of detecting intra-tumour heterogeneity and, thus, variations in differentiation, angiogenesis, and the extracellular matrix (5). Textural analysis (TA) is a new non-invasive technique that can be applied to various images such as those of radiography, ultrasound, MDCT, magnetic resonance imaging, and positron emission tomography; TA assesses spatial changes in tumoural gray level densities (5). TA has attracted particular attention in the context of malignant tumour imaging, and may be used to estimate tumour stage, grade, treatment response, and prognosis (6-9). The diagnostic accuracy of MDCT in terms of T-staging improves from early to advanced stages, but remains unsatisfactory because it is difficult to evaluate all gastric wall layers, particularly the minor curvature (10). However, to the best of our knowledge, no previous report has explored whether TA can detect stage T4 locally advanced GC. Therefore, we retrospectively analysed whether first-order histogram analysis of the preoperative computed tomography "CT" textural features of locally advanced GC patients could be used to predict stage T4 disease.

\section{Methods}

\section{Ethics}

This single-centre retrospective study adhered to all relevant tenets of the Helsinki Declaration and the Good Clinical Practice Guidelines and was approved by University of Health Sciences Turkey, İstanbul Training and Research Hospital Medical Ethics Committee (approval number: 1750, date: 15.03.2019). All patients were included after their informed consent was obtained.

We retrieved images taken from January 2017 to December 2019 from our archiving system.

\section{Patients}

A total of 148 consecutive patients who underwent radical gastrectomy with standard D1+/D2 lymph node dissection to treat locally advanced GC between January 2017 and December 2019 in our hospital were retrospectively analysed. The inclusion criteria were: the availablility of contrast-enhanced CT images taken in our institution within 4 weeks before surgery and histologically confirmed GC. We excluded patients who were very weak because they lacked adequate adipose tissue in the perigastric region in which regions of interest (ROIs) were drawn for TA ( $n=21$ ), and also those whose images afforded only poor tumour visualisation because of inadequate distension or peristalsis $(n=17)$ We finally included $110 \mathrm{GC}$ patients who underwent CT.

\section{CT image acquisition}

CT was performed using a 128-detector scanner (Philips Ingenuity, the Netherlands) or a 64-detector scanner (Aquilion, Canon Medical Systems, Japan). The usual MDCT scan parameters were: 1) $120 \mathrm{kVp}$; 2) 80-500 $\mathrm{mA}$; 3) slice thickness $2 \mathrm{~mm}$; 4) pitch 0.797-1.5; 5) field-of-view 50x50 $\mathrm{cm}$; 6) rotation time $0.5-0.75 \mathrm{~s}$; 7) window level 400 (200-600); 8) window width 40 (30-60); 9) matrix 512x512; and, 10) reconstruction interval $0.4 \mathrm{~mm}$ for 128 -detector CT and $0.5 \mathrm{~mm}$ for 64 -detector CT. A nonionic intravenous contrast agent ( $2 \mathrm{~mL} / \mathrm{kg}$ iopromide (maximum: $150 \mathrm{~mL}$ ); Ultravist 370: Bayer, Berlin, Germany) was delivered via an automatic injector (Optivantage) (Mallinckrodt, 2010); the volume varied by patient weight. Patient drank 1000-1500 mL of water and was injected with a hypotonic agent (20 mg of scopolamine) to distend the stomach before CT scanning.

\section{Image preprocessing}

All CT images were labelled, anonymised, and recorded in Digital Imaging and Communication in Medicine format. Pixel gaps were resized and synchronised to a $1 \times 1 \mathrm{~mm}^{2}$ in-plane resolution using free 3D-slicer software (ver. 4.10.2). To minimise the effects of differences between the two CT devices, image normalisation and grey level discretisation were performed by assigning a gray level range between 1 and $2 \mathrm{kbits} /$ pixel (termed K-values); the MaZda software (see below) analysed only images with $\mathrm{K}$-values of 6 . All images were normalised using the \pm 3 -sigma technique $(11,12)$.

\section{Texture analysis}

Preoperative CT images were retrieved from our archive and loaded onto an independent workstation for TA in random order. CT-TA was performed with the aid of MaZda software (ver. 4.6, P.M. Szczypiński, Institute of Electronics, Technical University of Lodz), which is free for research purposes (12). The first line of each region of interest (ROI) was drawn parallel to the gastric wall via the consensus of two radiologists (Aytül Hande Yardımcı and İpek Sel with 12 and 4 years of experience respectively, blinded to histopathological data). When expanding the ROI, the radiologists were careful to avoid large vessels and adjacent organs. In the section exhibiting the greatest portion of the tumour, a line was drawn to the outer tumour boundary. Three-fold dilatation was then performed using MaZda, and the area of perigastric area invasion within the ROI expanded toward that area. All tumour masses were evaluated separately (Figure 1a-c). The software automatically calculated all pixel attenuations within the ROI and generated 275 feature variables including first-, second-, and higher-order statistics for each patient (http://www.Eletel.p.lodz.pl/programy/MaZda). We used only the histogram features (1, 10, 50, 90, and 99\% percentiles; minimum, mean, and maximum norm; variance; skewness, and kurtosis). All images were from the portal venous phase. The cases were divided in to two groups by tumour T-stage [T 4 (a, b) and T1-to-3]; calculations were performed separately for each group.

\section{Statistical Analysis}

The descriptive statistics include the mean, median, standard deviation, minimum, maximum, and percentage. The distributions of all variables 
were checked with the aid of the Kolmogorov-Smirnov test. The Independent-samples t-test and the Mann-Whitney $U$ test were used (as appropriate) to compare quantitative data. The chi-squared test was employed to compare qualitative data. Receiver operator curve analysis was performed to assess whether various features were of diagnostic utility. SPSS ver. 26.0 software was used for all statistical analyses.

\section{Surgical resection}

All GC resections was performed according to the Japanese Gastric Cancer Society guidelines (13). Radical gastrectomy and standard D1/D2 lymph node dissection were performed by surgeons expert in gastrointestinal system procedures; all cases had pathologically confirmed GC.

\section{Pathological analysis and the reference standard}

Specimens were evaluated by reference to edition 8 of the Tumour, Node, Metastasis staging system by two pathologists with 5 and 10 years of experience.

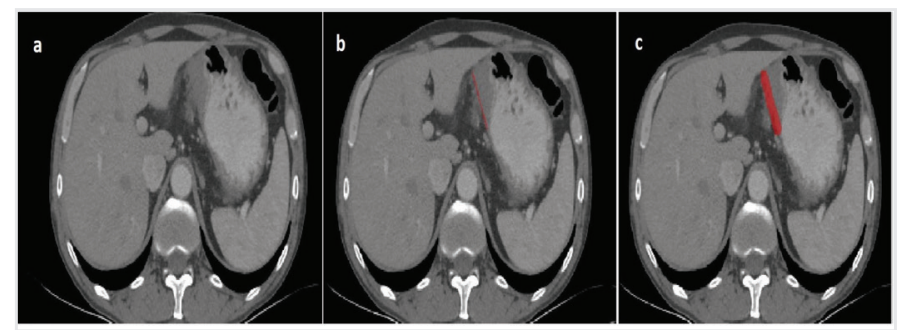

Figure 1. In picture (a), the single largest segment showing the perigastric tumor extension was selected and the tumor margins were determined, then a line showing the largest portion of the tumor (b) was drawn using Mazda software. Then, using the program, three-fold dilatation was performed sequentially (c) and a standard perigastric area to be analyzed within the ROI boundaries was provided

ROI: Regions of interest

\section{Results}

\section{Patient data}

A total of 110 patients with histopathologically proven GC were enrolled, of whom 10 had stage T1, 9 T2, 28 T3, and 63 T4 a,b disease. Eightyfour (76.4\%) patients were male and 26 (23.6\%) female. Histologically, 50 tumours were tubular adenocarcinomas; four papillary adenocarcinomas; three mucinous adenocarcinomas; 13 poorly cohesive carcinomas (including signet ring cell carcinomas and other variants); and 40 mixed adenocarcinomas (tubular, papillary, mucinous, medullary and poorly cohesive G(s).

\section{Histogram analysis}

Neither age nor gender differed significantly between the T1-to-T3 and $\mathrm{T} 4$ groups (both $\mathrm{p}>0.05$ ). Stage T4 tumours were significantly larger in size than stage T1-to-T3 tumours $(p<0.05)$. In the T4 group, the min, max, and mean norms; and the 1, 10, and 50\% percentiles were significantly lower than in the T1-to-T3 group (all $p<0.05$ ). Neither the 90 nor $99 \%$ percentiles differed between the two groups (both $p>0.05$ ). The T4 variance was significantly greater than that of the T1-to-T3 group $(p<0.05)$. The T4 skewness was significantly lower than that of the T1to-T3 group $(p<0.05)$ but the T4 kurtosis significantly higher $(p<0.05)$ (Table 1, 2). The mean AUCs and classification accuracies with $95 \%$ confidence intervals are listed in Table 3.

\section{Discussion}

Locally advanced GC is defined as stage T4 disease in which the tumour perforates the serosa (T4a) or invades adjacent structures (T4b), and often has a poor prognosis because of the presence of peritoneal seeding, liver metastasis, and/or distant lymph node involvement (14). CT-TA has recently been considered a promising tool; CT-TA evaluates gray level

\section{Table 1. Tumor size, age, gender distribution and histogram analysis findings among the T4 and T1,2,3 groups of the patients are} summarized

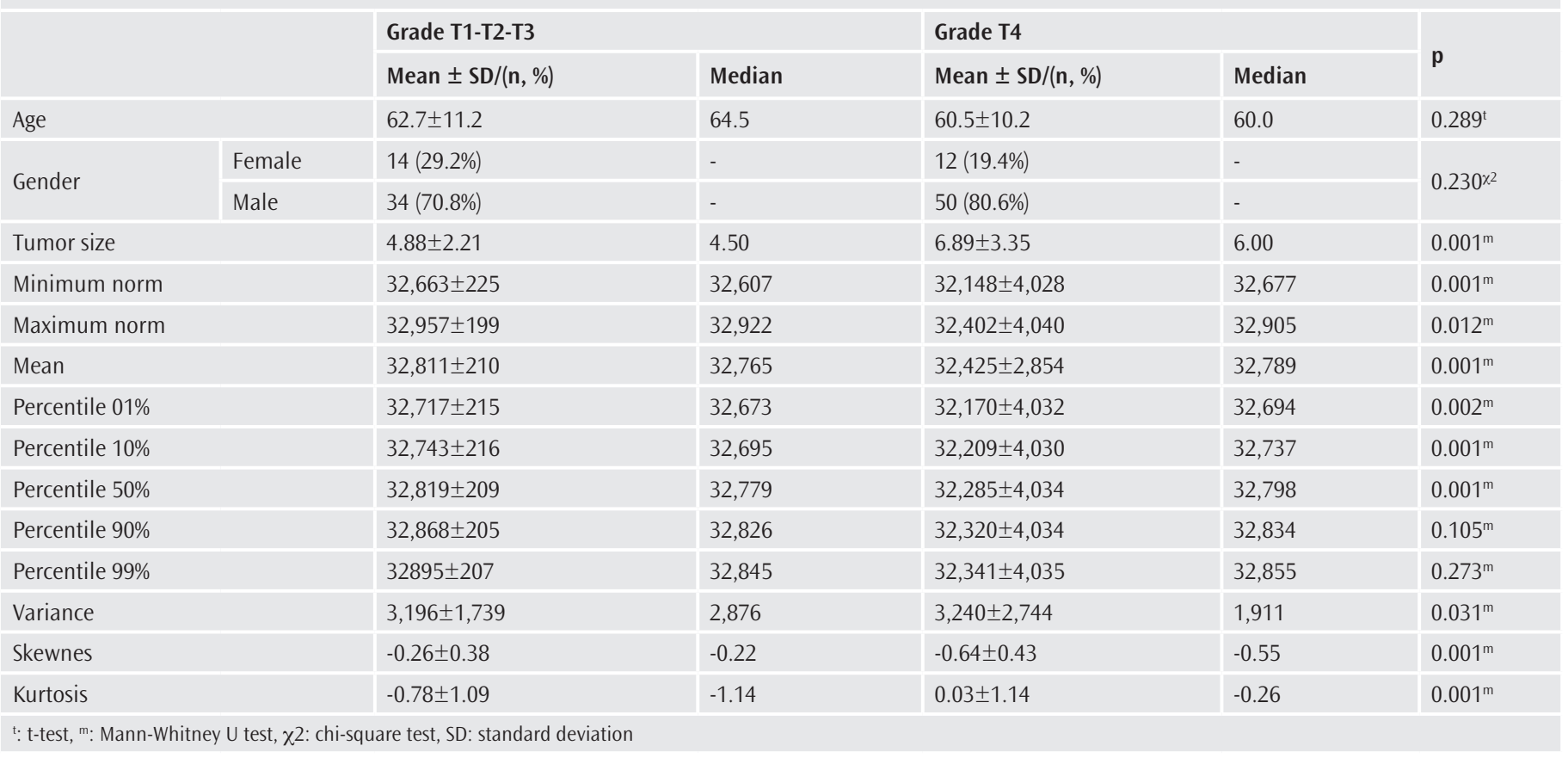


Table 2. Stage T4 tumors were significantly larger in size than stage T1-to-T3 tumors $(\mathbf{p}<0.05)$ in the left graphics on Table 2 . All histogram parameters between stages 4 and stages 1-3 are listed in Table 2 and the right graphics

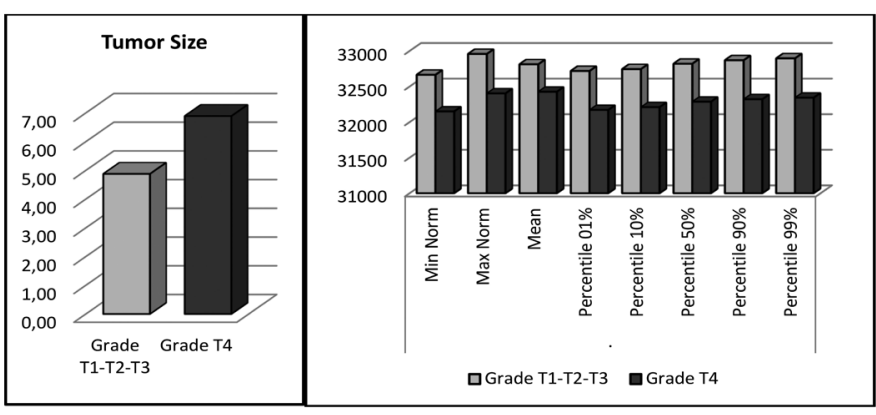

Table 3. The mean AUCs and classification accuracies with $95 \%$ confidence intervals are listed in Table 3

\begin{tabular}{|l|l|l|l|}
\hline & AUC & $\mathbf{9 5} \% \mathbf{C l}$ & $\mathbf{p}$ \\
\hline Skewnes & 0.798 & $0.711-0.885$ & $\mathbf{0 . 0 0 0}$ \\
\hline Kurtosis & 0.776 & $0.684-0.868$ & $\mathbf{0 . 0 0 0}$ \\
\hline Minimum norm & 0.743 & $0.645-0.841$ & $\mathbf{0 . 0 0 0}$ \\
\hline Mean & 0.715 & $0.614-0.817$ & $\mathbf{0 . 0 0 0}$ \\
\hline Percentile 10\% & 0.718 & $0.617-0.819$ & $\mathbf{0 . 0 0 0}$ \\
\hline Percentile 50\% & 0.715 & $0.614-0.816$ & $\mathbf{0 . 0 0 0}$ \\
\hline Tumor size & 0.681 & $0.582-0.779$ & $\mathbf{0 . 0 0 1}$ \\
\hline Percentile 01\% & 0.669 & $0.564-0.774$ & $\mathbf{0 . 0 0 2}$ \\
\hline Maximum norm & 0.640 & $0.535-0.746$ & $\mathbf{0 . 0 1 2}$ \\
\hline Variance & 0.620 & $0.513-0.727$ & $\mathbf{0 . 0 3 1}$ \\
\hline Percentile 90\% & 0.590 & $0.482-0.699$ & 0.105 \\
\hline Percentile 99\% & 0.561 & $0.451-0.671$ & 0.273 \\
\hline Receiver operating characteristic curve. & & \\
\hline AUC: Area under the curve, Cl: confidence interval & & \\
\hline
\end{tabular}

distributions and spatial intratumoural heterogeneities (15). Earlier studies suggested that CT-TA might usefully evaluate GC clinical stage, pathological grade, and prognosis $(16,17)$. However, CT-TA has not previously been used to detect serosal invasion (stage-T4) GC. We found significant differences in tumour size; the minimum, maximum, and mean norms; the 1, 10, and 50\% percentiles; variance; skewness; and kurtosis between the T4 and T1-to-T3 stages. Skewness derived from portal venous phase images most accurately (AUC: 0.798) distinguished T4 from T1-to-T3 disease. CT attenuation reflects tumour enhancement (18); higher attenuation probably reflects the higher vascularity of more aggressive tumours.

We found that lower skewness and higher kurtosis were significantly associated with T4 status and serosal invasion. Higher skewness and lower kurtosis were significantly associated with the presence of a K-ras mutation in non-small cell lung cancer patients in the study of Weiss et al. (19). Feng et al. (20) showed that volumetric CT textural features, particularly entropy, could potentially serve as biomarkers for risk stratification of small intestinal/gastrointestinal stromal tumours. Here, we performed first-order histogram analysis of single slices; thus, not entire tumours. Previous studies found that CT-TA predicted GC histopathological characteristics (16-20). Liu et al. (17) reported that the invasiveness of tumours of different grades depended principally on the extent of neovascularisation, reflected by attenuation of contrastenhanced $\mathrm{CT}$.

\section{Study Limitations}

Our work had several limitations. First, this was a retrospective singlecentre study, with an inevitable patient selection bias. Second, we did not evaluate arterial phase data; this would aid determination of gastric wall invasion depth, especially early in disease progression.

Thirdly, when the perigastric area invasion of the tumor was evaluated after 3-fold dilatation using the MaZda program, both the perigastric and the area towards the tumor fell within the limits of the analysis. Considering different tumor types, this creates a limitation since it is analyzed in the tumor with the perigastric area, and in the next studies, the analysis by removing the tumor margin will give more successful results in evaluating the actual perigastric area invasion.

Finally, in weak patients, the absence of perigastric adipose tissue rendered it difficult to draw ROIs and perform CT-TA; we excluded such patients.

\section{Conclusion}

The histogram parameters of CT-TA, especially skewness and kurtosis derived from portal, venous phase CT images, may serve as biomarkers stratifying the risk of serosal invasion (stage-T4) by locally advanced GC. Thus, histogram analysis can be used preoperatively to evaluate serosal invasion.

Ethics Committee Approval: This single-centre retrospective study adhered to all relevant tenets of the Helsinki Declaration and the Good Clinical Practice Guidelines and was approved by University of Health Sciences Turkey, İstanbul Training and Research Hospital Medical Ethics Committee (approval number: 1750, date: 15.03.2019).

Informed Consent: All patients were included after their informed consent was obtained.

Peer-review: Externally peer-reviewed.

Authorship Contributions: Surgical and Medical Practices - V.H.Y.; Concept - A.H.Y., V.H.Y., I.S., C.T.B.; Design - A.H.Y., Ö.M., C.T.B.; Data Collection or Processing - Ö.M., I.S.; Analysis or Interpretation - A.H.Y., C.T.B.; Literature Search - Ö.M., V.H.Y., I.S.; Writing - A.H.Y.

Conflict of Interest: No conflict of interest was declared by the authors.

Financial Disclosure: The authors declared that this study received no financial support.

\section{References}

1. Global Burden of Disease Cancer Collaboration, Fitzmaurice C, Abate D, Abbasi N, Abbastabar H, Abd-Allah F, Abdel-Rahman O, et al. Global, Regional, and National Cancer Incidence, Mortality, Years of Life Lost, Years Lived With Disability, and Disability-Adjusted Life-Years for 29 Cancer Groups, 1990 to 2017: A Systematic Analysis for the Global Burden of Disease Study. JAMA Oncol 2019; 5: 1749-68. 
2. Li W, Qin J, Sun YH, Liu TS. Neoadjuvant chemotherapy for advanced gastric cancer: a meta-analysis. World J Gastroenterol 2010; 16: 5621-8.

3. Niekel MC, Bipat S, Stoker J. Diagnostic imaging of colorectal liver metastases with CT, MR imaging, FDG PET, and/or FDG PET/CT: a meta-analysis of prospective studies including patients who have not previously undergone treatment. Radiology 2010; 257: 674-84.

4. Fukuya T, Honda H, Hayashi T, Kaneko K, Tateshi Y, Ro T, et al. Lymph-node metastases: efficacy for detection with helical CT in patients with gastric cancer. Radiology 1995; 197: 705-11.

5. Davnall F, Yip CS, Ljungqvist G, Selmi M, Ng F, Sanghera B, et al. Assessment of tumor heterogeneity: an emerging imaging tool for clinical practice? Insights Imaging 2012; 3: 573-89.

6. Yip C, Landau D, Kozarski R, Ganeshan B, Thomas R, Michaelidou A, et al. Primary esophageal cancer: heterogeneity as potential prognostic biomarker in patients treated with definitive chemotherapy and radiation therapy. Radiology 2014; 270: 141-8.

7. Yoon SH, Kim YH, Lee YJ, Park J, Kim JW, Lee HS, et al. (2016) Tumor Heterogeneity in Human Epidermal Growth Factor Receptor 2 (HER2)-Positive Advanced Gastric Cancer Assessed by CT Texture Analysis: Association with Survival after Trastuzumab Treatment. PLoS One 2016; 11: e0161278.

8. Ganeshan B, Skogen K, Pressney I, Coutroubis D, Miles K. Tumour heterogeneity in oesophageal cancer assessed by CT texture analysis: preliminary evidence of an association with tumour metabolism, stage, and survival. Clin Radiol 2012; 67: 157-64.

9. Ng F, Ganeshan B, Kozarski R, Miles KA, Goh V. Assessment of primary colorectal cancer heterogeneity by using whole-tumor texture analysis: contrast-enhanced CT texture as a biomarker of 5-year survival. Radiology 2013; 266: 177-84.

10. Minami M, Kawauchi N, Itai Y, Niki T, Sasaki Y. Gastric tumors: radiologicpathologic correlation and accuracy of T staging with dynamic CT. Radiology 1992; 185: 173-8.
11. Szczypiński PM, Strzelecki M, Materka A, Klepaczko A. MaZda--a software package for image texture analysis. Comput Methods Programs Biomed 2009; 94: 66-76.

12. Collewet G, Strzelecki M, Mariette F. Influence of MRI acquisition protocols and image intensity normalization methods on texture classification. Magn Reson Imaging 2004; 22: 81-91.

13. Japanese Gastric Cancer Association. Japanese gastric cancer treatment guidelines 2014 (ver. 4). Gastric Cancer 2017; 20: 1-19.

14. Fukuda N, Sugiyama Y, Wada J. Prognostic factors of T4 gastric cancer patients undergoing potentially curative resection. World J Gastroenterol 2011; 17 : $1180-4$.

15. Lubner MG, Smith AD, Sandrasegaran K, Sahani DV, Pickhardt PJ. CT Texture Analysis: Definitions, Applications, Biologic Correlates, and Challenges. Radiographics 2017; 37: 1483-503.

16. Ba-Ssalamah A, Muin D, Schernthaner R, Kulinna-Cosentini C, Bastati N, Stift J, et al. Texture-based classification of different gastric tumors at contrastenhanced CT. Eur J Radiol 2013; 82: 537-43

17. Liu S, Liu S, Ji C, Zheng H, Pan X, Zhang Y, et al. Application of CT texture analysis in predicting histopathological characteristics of gastric cancers. Eur Radiol 2017; 27: 4951-9.

18. Giganti F, Antunes S, Salerno A, Ambrosi A, Marra P, Nicoletti R, et al. Gastric cancer: texture analysis from multidetector computed tomography as a potential preoperative prognostic biomarker. Eur Radiol 2017; 27: 1831-9.

19. Weiss GJ, Ganeshan B, Miles KA, Campbell DH, Cheung PY, Frank S, et al. Noninvasive image texture analysis differentiates K-ras mutation from panwildtype NSCLC and is prognostic. PLoS One 2014; 9: e100244.

20. Feng C, Lu F, Shen Y, Li A, Yu H, Tang H, et al. Tumor heterogeneity in gastrointestinal stromal tumors of the small bowel: volumetric CT texture analysis as a potential biomarker for risk stratification. Cancer Imaging 2018; 18: 46. 